\title{
Letter to the Editor: Enzyme Replacement Therapy by Transplantation of HLA-Compatible Fibroblasts in Sanfilippo Syndrome: Another Trial
}

\author{
A. MUNNiCH, J. M. SAUdubRAY, M. C. HORS-CAYLA, L. POENARU, H. OGIER, G. STRECKER, \\ J. AICARDI, J. FREZAL, AND P. MAROTEAUX
}

Medical Genetic Research Unit (INSERM 12), Hospital for Sick Children, Paris, France

In the past few years, several transplantations of enzyme-producing cells or tissues have been performed in an attempt to continuously produce active enzymes in patients suffering from mucopolysaccharidoses $(1,2,3)$.

Reporting the successful results of HLA-compatible fibroblast transplantation in patients with Sanfilippo A syndrome, Dean et al. (1) suggested that the implanted donor fibroblasts could survive for a long period of time and possibly even increase in number in the recipients' subcutaneous space thus becoming a suitable source of normal enzymes in affected children.

We have recently performed a similar transplantation in a 9year-old girl with Sanfilippo type B syndrome. Our patient had clinical features and heparane sulfaturia typical of Sanfilippo disease. The diagnosis of Sanfilippo type B disease was confirmed by the demonstration of a complete deficiency of $\mathrm{N}$-acetyl- $\alpha$ glucosaminidase activity in plasma and cultured fibroblasts (6). Both parents had a low enzyme activity in their serum (4.2 and $3.9 \mathrm{nmole} / \mathrm{h} / \mathrm{ml}$ for the mother and the father respectively; control mean \pm 1 S.D. $=16.7 \pm 6.7 \mathrm{nmole} / \mathrm{h} / \mathrm{ml}, n=19$ ) but they were clinically normal and they had no heparane sulfaturia.

The donor was the patient's brother. He had normal enzyme activity in cultured fibroblasts as compared to control value (47.4 $\mathrm{nmole} / \mathrm{h} / \mathrm{mg}$ protein; control $=20.4 \mathrm{nmole} / \mathrm{h} / \mathrm{mg}$ ). Before grafting, the ability of donor cells to correct the catalytic abnormality in the recipients' fibroblasts was confirmed in culture as described (5). The donor was HLA-identical to his sister and he displayed no mixed leukocyte reaction against the recipient. Fibroblast culture and transplantation were performed as described (1), and approximately $2 \times 10^{8}$ viable cells were injected as a cell suspension into four subcutaneous dorsal sites, which were located by dermatological methods.

$\mathrm{N}$-acetyl- $\alpha$-glucosaminidase activity in serum and glycosaminoglycan (GAG) elimination in the urines were followed before and after transplantation. As shown in Figure 1, no significant modifications in enzyme activity were noted in serum after grafting and the excretion of urinary GAG remained unchanged over a period of 4 months.

In order to evaluate the implantation of donor fibroblasts in the recipients' tissues, our patient under';ent three full-thickness skin biopsies at the very same place where cell suspension was injected 2 months earlier. The fibroblasts cultured from these biopsies were tested for enzyme activity. The activity was found to be zero in the three independent specimens tested.

In addition, only female caryotypes were found in the cultured cells which were examined.

These data suggest that in our patient, the implanted fibroblasts did not survive or proliferate in situ. The failure to produce any measurable effect also precludes the possibility of a significant cell proliferation elsewhere. Thus, the results of our cell-transplantation in Sanfilippo B syndrome differ from those recently reported by Dean et al., (1) in the Sanfilippo A syndrome.

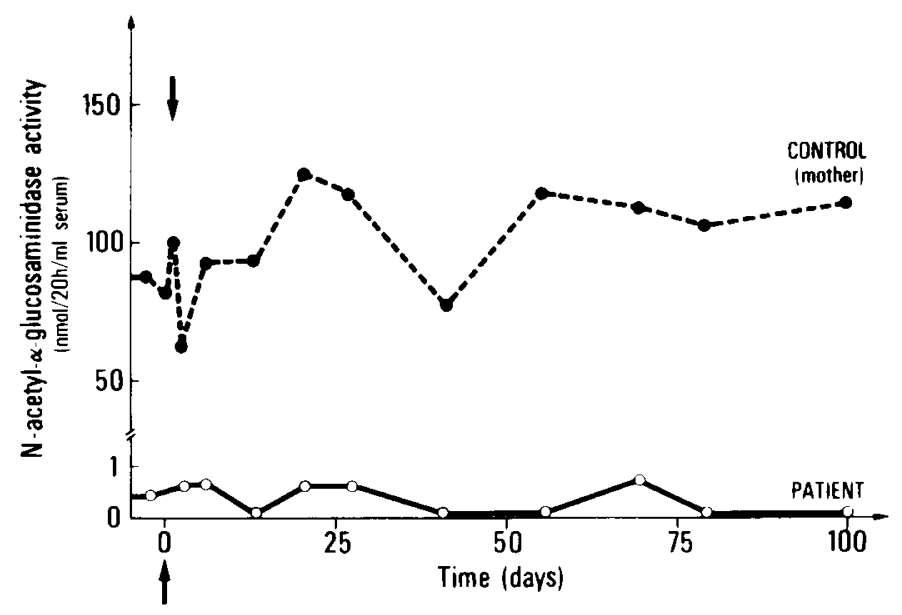

Fig. 1. $\mathrm{N}$-acetyl- $\alpha$-glucosaminidase activity in serum from Sanfilippo B patient before and after subcutaneous injection of HLA-compatible fibroblasts. $2 \times 10^{8}$ viable cells were injected subcutaneously into four different dorsal sites, at day 0 (arrow). Blood from the patient and from the control (mother) was taken after a $12-\mathrm{h}$ physiologic fast. The enzyme activity was measured on the serum after a $20 \mathrm{~h}$ incubation, according to a method slightly modified from Von Figura (6), until day 100.

Indeed, the intracellular half-life of $\mathrm{N}$-acetyl- $\alpha$-glucosaminidase is known to be short (5); infusions of HLA-compatible leukocytes in Sanfilippo B disease only resulted in a transient effect on urinary GAG excretion (4). However, this explanation could not account for our results if one assumes that implanted donor fibroblasts can survive and even proliferate in the recipients' subcutaneous space (1).

Consequently, in spite of the negativity of mixed leukocyte reaction after grafting, one has to consider the possibility of a graft rejection, especially as no immunosuppressive therapy was given.

In our opinion, the decision of an immunosuppressive therapy for fibroblast transplantation is questionable. We are reluctant to take such a heavy decision for a therapeutic trial which has little chance of clinical success if one compares the amount of accumulated substances to the small number of transplanted cells. However, in contrast to cell transplantation, an immunosuppressive therapy could be reasonably decided for an organ transplantation since the risk of an efficient immunosuppression is counterbalanced by the expectation of a possible clinical improvement.

\section{REFERENCES AND NOTES}

1. Dean, M. F., Muir, H., Benson, P. F. and Button, L. R.: Enzyme replacement therapy by transplantation of HLA-compatible fibroblasts in Sanfilippo A syndrome. Pediatr. Res. 15: 959 (1981). 
2. Dean, M. F., Muir, H., Benson, P. F., Button, L. R., Batchelor, J. R. and Bewick, $M$.: Increased breakdown of glycosaminoglycans and appearance of corrective enzyme after skin transplants in Hunter syndrome. Nature 257: 609 (1975).

3. Dean, M. F., Stevens, R. L., Muir, H., Benson, P. F., Button, L. R., Anderson, L. R., Boylston, A. and Mowbray, J.: Enzyme replacement therapy by fibroblast transplantation. J. Clin. Invest. 63: 138 (1979).

4. Moser, H. W., O'Brien, J. S., Atkins, L., Fuller, T. C., Keiman, A., Janowska, S., Russel, P. F., Bartsocas, C. S., Cosimi, B. and Dulaney, J. T.: Infusion of normal HLA-identical leukocytes in Sanfilippo disease type B. Arch. Neurol.,

\section{1: 329 (1974).}

5. O'Brien, J. S., Miller, A. L., Loverde, A. W. and Veath, M. L.: Sanfilippo disease type B: enzyme replacement and metabolic correction in cultured fibroblasts. Science, I81: 753 (1973).

6. von Figura, K., Lögering, M., Mersmann, G. and Kresse, H.: Sanfilippo B disease: serum assays for detection of homozygous and heterozygous individuals. J. Pediatr., 83: 607 (1973).

7. We are indebted to Mrs. S. Heuertz for her skillful technical assistance.

\title{
Letter to the Editor: Effectiveness of HLA- Compatible Fibroblasts for Enzyme Replacement Therapy in the Mucopolysaccharidoses
}

\author{
M. F. DEAN, HELEN MUIR, P. F. BENSON, AND L. R. BUTTON \\ Division of Biochemistry, Kennedy Institute, London, U.K. and Pediatric Research Unit, Guy's Hospital Tower, \\ London, $U . K$.
}

We transplanted HLA compatible fibroblasts into several patients with different types of mucopolysaccharidoses in an attempt to provide a long lasting source of lysosomal enzymes for replacement therapy (Dean et al. 3, 4, 5).

In one group of patients deficient in $\alpha$-L-idurono-2-sulphate sulphatase (Hunter syndrome) and another group deficient in glucosamine-N-sulphate sulphatase (Sanfilippo A syndrome), we observed a number of biochemical changes subsequent to a single transplant. These changes included increased excretion of accumulated glycosaminoglycan storage products, a reduction in the relative proportions of higher molecular weight oligosaccharides and a marked reduction in their degree of oversulphation. Coupled with these changes we observed an increase in the activity of previously deficient lysosomal enzymes measured as excreted "corrective factors". All the above effects persisted for many months.

However, we were unable to demonstrate any consistent changes following a similar transplant in a group of two patients with $\alpha$-L-iduronidase deficiency (Hurler syndrome), Dean et al. unpublished data. Neither were we able to detect a consistent increase in glucosamine- $\mathrm{N}$-sulphatase activity in our patients with Sanfilippo disease when $\left[{ }^{35} \mathrm{~S}\right]$-labeled heparin was used as a substrate for direct enzyme assay. Leucocytes and serum samples taken from two of our Hunter patients more than a year after transplant did, however, have slightly higher levels of $\alpha$-L-idurono2-sulphate sulphatase than age matched control untreated patients when tested against a [ $\left.{ }^{3} \mathrm{H}\right]$-labeled disulphated disaccharide substrate.

All our patients exhibited severe primary and secondary symptoms of their diseases prior to transplant and we did not detect sustained clinical improvements in any of them following treatment.

The intracellular half lives of most lysosomal enzymes are very short, $\alpha$-L-idurono-2-sulphate sulphatase and glucosamine-N-sulphatase for example each being only 2 days after uptake into fibroblasts [Cantz et al., (2), Kresse and Neufeld (7)]. The long lasting effects we observed following single transplants of fibroblasts could only therefore be explained if at least some of the fibroblasts had survived and continued to secrete lysosomal enzymes. The fact that a relatively small number of transplanted cells induced such large changes in excreted enzymes and GAG led us to speculate that perhaps the transplanted cells may have divided in vivo. We do not however have any direct evidence that either supposition is correct.
Transplanted fibroblasts have produced measurable effects in other patients; Gibbs et al. (6) for example noted changes in excreted GAG in Hunter patients. On the other hand Munnich et al. (8) could detect no changes when they transplanted fibroblasts into a patient with Sanfilippo B syndrome. We do not have enough information to explain this variability in results.

We ourselves have no experience with Sanfilippo B patients. Since this syndrome results from a glycosidase deficiency rather than absence of a sulphatase, however, it may be less amenable to replacement therapy than sulphatase deficiencies such as Hunter and Sanfilippo A diseases. Furthermore, since each lysosomal enzyme deficiency other than those within the same pedigree is attributable to a separate gene mutation, there may be considerable variation in responsiveness even within a group of patients with the same inborn error. Other discrepancies may result from differences in experimental protocol. Lack of immunosuppression before transplant for example may explain the failure of graft survival. The method employed for enzyme assay is also important. Detection of previously deficient enzymes by correction of $\left[{ }^{35} \mathrm{~S}\right]$-sulphate incorporation has been shown to be 14 times more sensitive than direct enzyme assay in the case of $\beta$-glucuronidase [Brot et al. (1)]. Very low amounts of lysosomal enzymes, which may be present in serum or urine following transplants, may thus be undetectable by direct assay but demonstrable indirectly by their ability to reduce $\left[{ }^{35} \mathrm{~S}\right]$-sulphate incorporation in patients' cells. Finally, the failure to identify donor cells at the site of transplantation or to demonstrate $\mathrm{N}$-acetyl- $\alpha$-glucosaminidase activity there reported by Munnich et al. (8) may be explained by the fact that their biopsy was limited to full-thickness skin. Donor fibroblasts transplanted into deeper subcutaneous sites may not therefore have been revealed.

\section{REFERENCES AND NOTES}

1. Brot, E. F., Glaser, J. H., Roozen, K. J. and Sly, W. S.: In vitro correction of deficient human fibroblasts by $\beta$-glucuronidase from different human sources. Biochem. Biophys. Res. Commun., 57: 1 (1974)

2. Cantz, M., Chrambach, A., Bach, G. and Neufeld, E. F.: The Hunter corrective factor: purification and preliminary characterisation. J. Biol. Chem.. 247; 5456 (1972).

3. Dean, M. F., Muir, H., Benson, P. and Button, L. R.: Enzyme replacement therapy in the Mucopolysaccharidoses by fibroblast transplantation. In: Birth Defects: Original Article Series, Vol. XVI, No. l. (Ed.) Desnick, R.J. pp. 445 456 (R.J. Liss Inc., New York, NY 1980).

4. Dean, M. F., Muir, H., Benson, P. F. and Button, L. R.: Enzyme replacement therapy by transplantation of HLA-compatible fibroblasts in Sanfilippo A syndrome. Pediatr. Res., 15: 959 (1981). 